\title{
ПРИМЕНЕНИЕ ИННОВАЦИОННЫХ ПРЕПАРАТОВ ЭКО-СТИМ В КАЧЕСТВЕ РЕГУЛЯТОРОВ РОСТА СЕЛЬСКОХОЗЯЙСТВЕННЫХ КУЛЬТУР*
}

\author{
(C) Е.В. Калюта ${ }^{* * 1}$, М.И. Мальцев ${ }^{1}$, В.И. Маркин ${ }^{2}$, И.Б. Катраков ${ }^{2}$, Н.Г. Базарнова ${ }^{2}$ \\ ${ }^{1}$ Алтайский государственный аграрный университет, пр. Красноармейский, \\ 98, Барнаул, 656049 (Россия) e-mail: kalyuta75@mail.ru \\ ${ }^{2}$ Алтайский государственный университет, пр. Ленина, 61, Барнаул, 656049 \\ (Россия), e-mail: markin@chem.asu.ru
}

\begin{abstract}
Сельскохозяйственные предприятия испытывают потребность в использовании доступных, дешевых стимуляторов роста растений, которые должны являться не только эффективными, но и экологически безопасными для окружающей среды. В настоящей работе исследован инновационный регулятор роста Эко-Стим, полученный карбоксиметилированием различных видов растительного сырья (древесина сосны, полова овса, лузга подсолнечника). Для его получения можно использовать отходы растениеводства, что также поможет решить проблему утилизации растительных отходов на предприятиях, занимающихся сельскохозяйственным производством. Изучено влияние способа применения Эко-Стим (внесение в виде порошка в почву, обработка семян водным раствором, полив растений на различных этапах вегетации) и вносимой дозы. Исследовано влияние препаратов Эко-Стим на рост и развитие пшеницы сорта «Омская-36», огурцов сорта «Засолочный», редиса сорта «Престо» как при промышленном производстве, так и при возделывании растений на малых площадях. Установлено, что все изученные препараты обладают росторегулирующей активностью и их можно применять в качестве регуляторов роста различных сельскохозяйственных культур при его внесении как в сухом виде, так и при обработке семян растворами или при поливе растений на различных стадиях вегетации. Наибольший ростостимулирующий эффект наблюдается при использовании водных растворов.
\end{abstract}

Ключевые слова: растительное сырье, карбоксиметилирование, стимулятор роста, ауксины, Эко-Стим.

\section{Введение}

Предприятия, перерабатывающие сельскохозяйственную продукцию, сталкиваются с серьезной проблемой утилизации отходов производства. Одним из возможных путей решения данной проблемы является химическая переработка растительных остатков с получением водорастворимых полимерных

Калюта Елена Владимировна - старший преподаватель кафедры химии, кандидат химических наук, e-mail: kalyuta75@mail.ru

Мальиев Михаил Ильич - доцент кафедры общего земледелия и растениеводства, кандидат сельскохозяйственных наук, e-mail: uoshs@mail.ru Маркин Вадим Иванович - доцент кафедры органической химии, кандидат химических наук, тел.: (3852) 29-81-36, e-mail: markin@chemwood.asu.ru Катраков Игорь Борисович - доцент кафедры органической химии, кандидат химических наук, тел.: (3852) 29-81-36, , e-mail: kib-22@yandex.ru Базарнова Наталья Григорьевна - заведующая кафедрой органической химии, профессор, доктор химических наук, тел.: (3852) 66-66-82, e-mail: bazarnova@chem.asu.ru продуктов, обладающих комплексом полезных свойств, в том числе и способностью активизировать рост растений. Применение биостимуляторов на основе продуктов переработки местного растительного сырья позволит повысить урожайность и сократить затраты при выращивании культур, существенно ослабить проблему утилизации отходов сельскохозяйственного производства.

Работы по изучению гормональной регуляторной системы растений проводятся достаточно давно. Систематизация большого количества фрагментарных данных о наличии эндогенных механиз-

\footnotetext{
* Данная статья имеет электронный дополнительный материал (приложение), который доступен читателям на сайте журнала. DOI: 10.14258/jcprm.2016021296s.

** Автор, с которым следует вести переписку.
} 
мов роста и развития растений и взаимосвязи между разными органами растений позволила сделать вывод о существовании неких химических соединений, с помощью которых происходят различные взаимодействия между отдельными органами растений. С момента открытия идолил-3-уксусной кислоты (ИУК) первого фитогормона ауксинового типа - проведено большое количество исследований в области фитогормонологии, которые позволили сформулировать теорию о существовании у растений эндогенной интегральной фитогормональной системы. К настоящему времени достигнуты значительные успехи в изучении путей биосинтеза большинства классов фитогормонов, а также механизма их действия на молекулярном уровне [1]. Общепризнанным является деление фитогормонов на пять классов: ауксины, гиббереллины, цитокинины, этилен и абсцизовая кислота. Причем, как показано последними исследованиями, эти соединения оказывают перекрестное регуляторное действие. Работы последних лет свидетельствуют о существовании других классов химических соединений, оказывающих регуляторное действие в растениях, которые также можно отнести к фитогормонам: олигосахариды и моносахариды [2, 3], жасмонаты, салицилаты, полиамины, тургорины и многие другие [4, 5]. Установлены и другие химические соединения природного происхождения, оказывающие стимулирующее действие (ауксинового типа), например, фенолкарбоновые кислоты (феруловая, ванильная, кофейная), производные мочевины, дигидрокониферол, а также некоторые витамины (аскорбиновая и никотиновая кислоты, тиамин).

На кафедре органической химии АлтГУ разработаны способы карбоксиметилирования лигноуглеводных материалов [6-9].

Карбоксиметилирование лигнина в составе растительного сырья приводит к образованию структур, сходных по своему строению с молекулами регуляторов роста ауксинового типа, характерной особенностью которых является наличие ароматического кольца или группы колец и боковой цепи с кислотной группой. Поэтому на основании известных литературных данных $[1,10]$ и теоретических предпосылок для карбоксиметилированных производных на основе растительного сырья можно ожидать росторегулирующую активность. Был проведен предварительный анализ основных возможных структур, которые могут образоваться при карбоксиметилировании фрагментов лигнина, образующихся в щелочной среде, в том числе и с использованием квантохимических расчетных методов [9, 11, 12]. Показано, что карбоксиметилированные фрагменты лигнина должны обладать ростостимулирующей активностью, сходной с известными ауксинами. Проведены как лабораторные эксперименты, так и испытания в промышленных условиях возможного использования карбоксиметилированного растительного сырья в качестве стимуляторов роста растений. Исследования, проведенные на огурцах [13], яровой мягкой пшенице [14], в теплицах ОАО «Индустриальный» при выращивании томатов [15], показали, что на стадии прорастания семян такие препараты обладают ростостимулирующей активностью предположительно ауксинового типа. Введение препаратов в питательные среды для микроклонального размножения на этапе укоренения оказывает стимулирующее действие на геммо- и ризогенез у ириса сибирского и копеечника чайного [16]. Использование какрбоксиметилированных производных в качестве прилипателя для обработки семян сои, как отдельно, так и совместно с ризоторфином, повышает показатели структуры урожая и урожайность сои [17]. Полученные препараты прошли процедуру оформления технических условий под названием Эко-Стим (ТУ 928900-005-02067818-2015. 01.04.2015), они проявляют росторегулирующие свойства, что подтверждено исследованиями в лабораторных условиях [18].

Цель работы - исследовать росторегулирующую активность препаратов Эко-Стим, полученных в полупромышленных условиях из различных видов растительного сырья, при выращивании пшеницы на базе сельхозпредприятий Алтайского края и некоторых овощных культур на малых площадях.

\section{Экспериментальная часть}

Карбоксиметилирование растительного сырья. В качестве исходного растительного сырья использовали древесину сосны (Pinus silvestris), а также отходы растениеводства: поло́ву (мякину) овса (Avenaecarinis L.) и лузгу подсолнечника (Helianthus annuus L.).

Содержание основных структурных компонентов в растительном сырье определяли по стандартным методикам [19]: целлюлозу - по методу Кюршнера (азотно-спиртовым методом), лигнин - с $72 \%$ серной кислотой в модификации Комарова. Содержание целлюлозы в исходной древесине сосны составило $50,5 \pm 0,9 \%$, лигнина - 24,0 $0,3 \%$, в полове овса - соответственно $49,0 \pm 0,7$ и $17,0 \pm 0,4 \%$ и в лузге подсолнечника $-31,3 \pm 0,4$ и $29,3 \pm 0,2 \%$. 
Карбоксиметилирование растительного сырья проводили в соответствии с разработанной методикой [18] в реакторе РВПЭ-0.2 (ООО «ЮВС», Обнинск).

Исследование продуктов карбоксиметилирования растительного сырья. Биопрепараты Эко-Стим О, полученный на основе половы овса, Эко-Стим П, полученный на основе подсолнечной лузги, и Эко-Стим Д, полученный на основе древесных опилок сосны, анализировали на содержание карбоксиметильных групп (КМГ), вводимых при реакции, методом кондуктометрического титрования. Растворимость полученных образцов определяли в соответствии с методикой, основанной на растворении продукта в воде и последующей фильтрации этого раствора через пористый стеклянный фильтр [20]. Карбоксиметилцеллюлозу (КМЦ) выделяли из карбоксиметилированного растительного сырья 15\% надуксусной кислотой в соответствии с методикой [21]. Карбоксиметилированный лигнин определяли с $72 \%$ серной кислотой в модификации Комарова [19].

Изучение росторегулирующей активности. Для изучения росторегулирующей активности препаратов Эко-Стим использовали различные сельскохозяйственные культуры: из зерновых культур - яровую мягкую пшеницу сорта «Омская-36», из овощных культур - огурцы сорта «Засолочный», из корнеплодных растений - редис сорта «Престо».

Росторегулирующее действие препаратов в полевых условиях на яровую мягкую пшеницу сорта «Омская-36» исследовали по двум направлениям: 1) внесение препаратов в сухом виде вместе с пшеницей; 2) посев пшеницы, предварительно обработанной водным раствором препарата. Норма посева пшеницы 5 млн всхожих зерен на 1 га.

Эксперимент по внесению препаратов в землю в сухом виде вместе с пшеницей проводили в полевых условиях Первомайского района в 2013-2014 гг. Расположение вариантов в четырехкратной повторности систематическое со смещением. Площадь делянок - $1 \mathrm{~m}^{2}$. В качестве сравнения изучали воздействие карбоксиметилцеллюлозы (марка КМЦ-М, изготовлена ОАО «БХК», Бийск) в тех же концентрациях. Препараты Эко-Стим вносили в почву в сухом виде в количестве 1,0 и 10,0 г/ 0,15 м².

Эксперимент по посеву пшеницы, предварительно обработанной водным раствором препарата, проводили в условиях АО «Кипринское» Шелаболихинского района в 2015 г. и ООО «Вектор» Калманского района в 2014-2015 гг. Действие препарата Эко-Стим Д изучали в виде раствора с концентрацией $0,165 \%$. Данным препаратом обрабатывали семена пшеницы на площади 10 га в день посева. Расчетная доза препарата - 330 г на 200 кг зерна. В качестве сравнения использовали препарат Барьер Колор, действующее вещество которого (по ИСО) - тебуконазол - относится к химической группе триазолов, обладает профилактическим и лечебным системным действием.

Росторегулирующее действие препаратов на огурцы изучали по следующей методике. По 10 семян огурцов раскладывали на фильтровальную бумагу в чашках Петри и заливали 15 мл растворов препаратов ЭкоСтим О и Эко-Стим П с концентрацией 0,5 г/л. Концентрация выбрана на основе модельных экспериментов, проведенных в лабораторных условиях [13]. В период с 14 по 21 мая наблюдали за прорастанием семян. Затем по три среднестатистических растения высаживали в грунт и продолжали наблюдать за развитием растений с 21 мая по 20 июня 2014 г. В качестве стандарта брали дистиллированную воду.

Семена редиса перед посевом калибровали для получения однородных всходов и дружного формирования корнеплодов, высевали вручную в подготовленную почву на глубину 1,5-2,0 см. Схема посева - пятистрочные ленты с расстоянием между лентами 70 см, между рядами - 15 см. В каждый рядок длиной 1 м высевали по 15 семян и вносили определенное количество исследуемого препарата. После достижения технической зрелости редис убирали методом сплошного выдергивания. После уборки с каждого варианта отбирали по пять среднестатистических растений, отмывали корни и раскладывали на фильтровальной бумаге для наблюдения за развитием растений. Затем растения взвешивали для учета урожайности. Эксперимент проводили с 5 августа по 4 сентября 2015 г.

Для проведения эксперимента готовили растворы препаратов Эко-Стим с концентрацией 0,5, 1,5 и 5,0 г/л. Вносили под растения по 150 мл раствора на один рядок или на 0,15 м² (расход при поливе 1 л/1 м²). За период вегетации обработку проводили 4 раза. В качестве стандарта изучали воздействие на редис разрешенного к применению в с/х препарата «Био мастер - универсальный» (ТУ 0325-001-58776432-04, изготовлен ООО «Экспресс кемикалс», Новосибирск), имеющий следующий состав (\%): N - 7, P - 10, К - 6; гуминовые вещества - 80; микроэлементы B, $\mathrm{Cu}, \mathrm{Fe}, \mathrm{Mn}, \mathrm{Mo}, \mathrm{Zn}$.

Статистическую обработку результатов исследований проводят методом дисперсионного анализа по Доспехову [22].

В электронном приложении к статье приведены фотографии образцов исследованных растений. 


\section{Обсуждение результатов}

В результате карбоксиметилирования растительного сырья получены препараты, химический состав которых приведен в таблице 1, и в дальнейшем использованы для испытаний в качестве регуляторов роста различных сельскохозяйственных растений.

Исследования по изучению влияния внесения сухих препаратов Эко-Стим на массу 1000 зерен яровой пшеницы в полевых условиях Первомайского района вегетационного периода 2013-2014 гг. обнаружили, что все препараты оказывали влияние на данный показатель. Установлено, что препараты, в зависимости от дозы их внесения, обладают как ростостимулирующим, так и ингибирующим действием, что согласуется с общепринятой теорией по влиянию ауксинов на рост растений. При дозе внесения 1 г на $0,15 \mathrm{~m}^{2}$ все биопрепараты давали увеличение массы 1000 зерен в сравнении с контрольным вариантом (без препаратов). Максимальный эффект отмечался на варианте с применением Эко-Стим П - прибавка массы зерна составила 8,1-8,7\%, минимальный - на варианте сравнения (Na-КМЦ) - 3,2-3,9\% (табл. 2). При увеличении дозы в 10 раз все изучаемые продукты ингибировали рост яровой пшеницы, и было отмечено снижение массы 1000 зерен от 0,1 до 5,7\%.

Исследования по изучению ростостимулирующего действия препарата Эко-Стим Д в виде предпосевной обработки семян на рост и развитие яровой пшеницы проводили на полях АО «Кипринское» и ООО «Вектор». Проведенная оценка роста и развития пшеницы на стадии кущения показала, что густота стояния растений по вариантам опыта практически не отличалась и варьировала от 440 до 480 шт./м². Однако отмечено существенное различие в развитии узла кущения растений пшеницы. При использовании препарата Эко-Стим всходы пшеницы, как надземной, так и подземной ее части, выглядят значительно мощнее в сравнении с контролем (без применения препаратов). Масса растений пшеницы в воздушно-сухом состоянии при использовании исследуемого препарата превышала массу контрольного варианта на 29,4-31,2\% (табл. 3).

Анализ структуры урожая пшеницы «Омская-36» показывает, что ростостимулирующее влияние препарата Эко-Стим Д, зафиксированное в начальные фазы роста культуры, проявляется и в дальнейшем на протяжении всего вегетационного периода. Так, к уборке пшеницы отмечено существенное преимущество растений по продуктивной кустистости, высоте стебля и длине колоса (табл. 4).

Таблица 1. Химический состав препаратов Эко-Стим

\begin{tabular}{l|c|c|c|c}
\hline \multirow{2}{*}{$\begin{array}{c}\text { Исходное растительное сырье } \\
\text { (обозначение продукта реакции) }\end{array}$} & $\begin{array}{c}\text { Свойства продуктов карбоксиметилирования, \% } \\
\text { рованная целлюлоза }\end{array}$ & $\begin{array}{c}\text { карбоксиметили- } \\
\text { рованный лигнин }\end{array}$ & КМГ & $\begin{array}{c}\text { растворимость } \\
\text { в воде }\end{array}$ \\
\cline { 2 - 5 } Полова овса (Эко-Стим О) & $28,7 \pm 0,4$ & $12,4 \pm 0,3$ & $13,3 \pm 0,3$ & $75,2 \pm 0,8$ \\
Лузга подсолнечника (Эко-Стим П) & $21,5 \pm 0,7$ & $17,1 \pm 0,4$ & $19,0 \pm 0,4$ \\
Древесина сосны (Эко-Стим Д) & $32,4 \pm 0,5$ & $16,5 \pm 0,2$ & $29,3 \pm 0,3$ \\
\hline
\end{tabular}

Таблица 2. Влияние препаратов Эко-Стим на массу 1000 зерен яровой пшеницы, 2013-2014 гг.

\begin{tabular}{|c|c|c|c|c|c|c|c|c|}
\hline \multirow{4}{*}{ Вариант } & \multicolumn{8}{|c|}{ Доза внесения препарата } \\
\hline & \multicolumn{4}{|c|}{$1 \Gamma$} & \multicolumn{4}{|c|}{10 г } \\
\hline & \multicolumn{2}{|c|}{ масса зерна } & \multicolumn{2}{|c|}{ \pm к контролю, \% } & \multicolumn{2}{|c|}{ масса зерна } & \multicolumn{2}{|c|}{ \pm к контролю, \% } \\
\hline & 2013 г. & 2014 г. & 2013 г. & 2014 г. & 2013 г. & 2014 г. & 2013 г. & 2014 г. \\
\hline Контроль & 2,59 & 1,23 & - & - & 2,59 & 1,23 & - & - \\
\hline Эко-Стим П & 2,82 & 1,33 & $+8,7$ & $+8,1$ & 2,47 & 1,29 & $-4,9$ & $+5,3$ \\
\hline Эко-Стим О & 2,73 & 1,29 & $+5,4$ & $+4,9$ & 2,50 & 1,27 & $-3,6$ & $+3,8$ \\
\hline Эко-Стим Д & 2,70 & 1,28 & $+4,1$ & $+4,1$ & 2,45 & 1,25 & $-5,7$ & $+3,2$ \\
\hline Na-КМЦ & 2,69 & 1,25 & $+3,9$ & $+3,2$ & 2,55 & 0,90 & $-1,5$ & $-0,1$ \\
\hline
\end{tabular}

Таблица 3. Масса пяти типичных растений пшеницы в воздушно-сухом состоянии, фаза развития - кущение

\begin{tabular}{|c|c|c|c|}
\hline \multirow{2}{*}{ Вариант } & \multirow{2}{*}{ Воздушно-сухая масса, г } & \multicolumn{2}{|c|}{ Отклонение от контроля } \\
\hline & & $\Gamma$ & $\%$ \\
\hline \multicolumn{4}{|c|}{ АО «Кипринское» } \\
\hline 1. Контроль & 1,15 & - & - \\
\hline 2. Эко-Стим Д & 1,49 & $+0,34$ & $+29,4$ \\
\hline 3. Барьер Колор & 1,38 & $+0,23$ & $+19,2$ \\
\hline \multicolumn{4}{|c|}{ ООО «Вектор» } \\
\hline 1. Контроль & 0,96 & - & - \\
\hline 2. Эко-Стим Д & 1,26 & $+0,30$ & $+31,2$ \\
\hline
\end{tabular}


Таблица 4. Элементы структуры урожая пшеницы «Омская-36» в полевых условиях (средние значения по 10 типичным растениям)

\begin{tabular}{|c|c|c|c|c|c|c|c|c|}
\hline \multicolumn{3}{|c|}{ Контроль } & \multicolumn{3}{|c|}{ Эко-Стим } & \multicolumn{3}{|c|}{ Барьер Колор } \\
\hline $\begin{array}{l}\text { высота } \\
\text { стебля }\end{array}$ & $\begin{array}{c}\text { количество } \\
\text { стеблей }\end{array}$ & $\begin{array}{c}\text { длина } \\
\text { колоса, см }\end{array}$ & $\begin{array}{l}\text { высота } \\
\text { стебля }\end{array}$ & $\begin{array}{c}\text { количество } \\
\text { стеблей }\end{array}$ & $\begin{array}{c}\text { длина } \\
\text { колоса, см }\end{array}$ & $\begin{array}{l}\text { высота } \\
\text { стебля }\end{array}$ & $\begin{array}{c}\text { количество } \\
\text { стеблей }\end{array}$ & $\begin{array}{c}\text { длина } \\
\text { колоса, см }\end{array}$ \\
\hline \multicolumn{9}{|c|}{ АО «Кипринское»» } \\
\hline 85,1 & 1 & 6,8 & 91,4 & 1,4 & 8,1 & 86,3 & 1 & 8,6 \\
\hline \multicolumn{9}{|c|}{ ООО «Вектор» } \\
\hline 67,5 & 1 & 5,2 & 86,7 & 1 & 6,4 & - & - & - \\
\hline
\end{tabular}

В результате проведенных исследований можно констатировать, что в условиях вегетационного периода 2015 г. препарат Эко-Стим Д проявил ростостимулирующий эффект - способствовал более мощному кущению пшеницы. В условиях АО «Кипринское» количество продуктивных стеблей к уборке в 1,4 раза превышало контрольный вариант. Продуктивная кустистость тесно коррелирует с продуктивностью культуры. Поэтому можно с высокой степенью вероятности предположить, что при таком превышении продуктивных стеблей прибавка урожайности от применения препарата составила 20-25\%.

Изучение влияния препаратов Эко-Стим на рост и развитие огурцов показало, что на стадии прорастания семян (с 19 по 21 мая) в чашках Петри наибольшее влияние на длину корня оказал препарат ЭкоСтим П. Прибавка длины корня в этот период на 27\% больше по сравнению с контрольным вариантом. После посадки проросших семян в грунт ростостимулирующее действие препарата продолжилось. Длина стебля огурцов под действием этого препарата 20 июня на 57,8\% выше по сравнению с контролем (табл. 5).

В результате изучения влияния препаратов Эко-Стим на биометрические показатели и продуктивность редиса установлено, что все изучаемые препараты оказали положительное влияние на количество взошедших семян (табл. 6). Наибольшая полевая всхожесть от посева наблюдается на варианте с применением препарата Эко-Стим П с концентрацией раствора 1,5 г/л.

Таблица 5. Влияние препаратов Эко-Стим на рост и развитие огурцов, 2014 г.

\begin{tabular}{|c|c|c|c|c|c|}
\hline \multirow{2}{*}{ Дата } & \multirow{2}{*}{ Препарат } & \multicolumn{4}{|c|}{ Средняя длина, см } \\
\hline & & корня & \pm к контролю, \% & стебля & \pm к контролю, \% \\
\hline \multirow[t]{3}{*}{19 мая } & Контроль & 3,6 & - & - & - \\
\hline & Эко-Стим O & 4,9 & $+36,1$ & - & - \\
\hline & Эко-Стим П & 4,4 & $+22,2$ & - & - \\
\hline \multirow[t]{3}{*}{21 мая } & Контроль & 6,3 & - & 4,5 & - \\
\hline & Эко-Стим О & 6,5 & $+3,2$ & 5,3 & $+17,8$ \\
\hline & Эко-Стим П & 8,4 & $+27,0$ & 5,3 & $+17,8$ \\
\hline \multirow[t]{3}{*}{9 июня } & Контроль & - & - & 4,9 & - \\
\hline & Эко-Стим O & - & - & 5,6 & $+14,3$ \\
\hline & Эко-Стим П & - & - & 6,1 & $+24,5$ \\
\hline \multirow[t]{3}{*}{20 июня } & Контроль & - & - & 26,3 & - \\
\hline & Эко-Стим О & - & - & 28,0 & $+6,5$ \\
\hline & Эко-Стим П & - & - & 41,5 & $+57,8$ \\
\hline
\end{tabular}

Таблица 6. Влияние биопрепаратов на полевую всхожесть семян редиса

\begin{tabular}{c|c|c|c}
\hline Препарат & Концентрация, г/л & Количество взошедших семян, шт. & Всхожесть семян, \% \\
\hline Контроль & - & 9 & 60 \\
\hline Эко-Стим О & 0,5 & 12 & 80 \\
& 1,5 & 13 & 87 \\
\hline Эко-Стим Д & 5,0 & 13 & 87 \\
& 0,5 & 13 & 80 \\
\hline Эко-Стим П & 1,5 & 12 & 80 \\
& 5,0 & 13 & 100 \\
\hline Био Мастер & 0,5 & 12 & 87 \\
\hline
\end{tabular}

Исследования по изучению влияния вида препарата и дозы его внесения на урожайность редиса в открытом грунте показали, что все препараты оказали влияние на данный показатель. Во всех вариантах 
происходит увеличение общей массы растений и массы корнеплодов по сравнению с контролем. Изучаемые препараты оказывают наибольшее влияние на продуктивность корнеплода редиса при концентрации 1,5 г/л. При использовании раствора этой концентрации биопрепарата Эко-Стим О продуктивность редиса увеличивается на 14\%, биопрепаратов Эко-Стим П и Эко-Стим Д - на 17\%. Для нашего исследования для сравнения был выбран препарат «Био Мастер», который на $80 \%$ состоит из гуминовых биологически активных веществ. Прибавка массы корнеплода при внесении «Био Мастера» составляет 13\% по сравнению с контрольным вариантом (табл. 7).

Таблица 7. Биометрические показатели редиса при уборке (2015г.)

\begin{tabular}{l|c|c|c|c|c|c|c}
\hline \multirow{2}{*}{ Препарат } & Концен- & \multicolumn{7}{|c}{ Биометрические показатели } \\
& $\begin{array}{c}\text { трция, } \\
\text { г/л }\end{array}$ & $\begin{array}{c}\text { масса } \\
\text { листьев, г }\end{array}$ & $\begin{array}{c} \pm \text { к } \\
\text { контролю, \% }\end{array}$ & $\begin{array}{c}\text { масса } \\
\text { корнеплода, г }\end{array}$ & $\begin{array}{c} \pm \text { к } \\
\text { контролю, \% }\end{array}$ & $\begin{array}{c}\text { масса листьев } / \\
\text { масса корнеплода }\end{array}$ & $\begin{array}{c}\text { масса } \\
\text { растения, г }\end{array}$ \\
\hline Контроль & - & 8,94 & - & 7,80 & - & $1 / 0,87$ & 16,74 \\
\hline Био Мастер & 1,5 & 8,29 & $\mathbf{- 7 , 2 7}$ & 8,84 & $+\mathbf{1 3 , 3 3}$ & $\mathbf{1 / 1 , 0 7}$ & $\mathbf{1 7 , 1 3}$ \\
\hline Эко-Стим О & 0,5 & 8,94 & 0 & 7,93 & $+1,67$ & $1 / 0,89$ & 16,87 \\
& 1,5 & 8,35 & $\mathbf{- 6 , 6 0}$ & 8,91 & $+\mathbf{1 4 , 2}$ & $1 / 1,07$ & $\mathbf{1 7 , 2 6}$ \\
& 5,0 & 9,18 & $+2,68$ & 7,88 & $+1,03$ & $1 / 0,86$ & 17,06 \\
\hline Эко-Стим П & 0,5 & 8,98 & $+0,45$ & 7,97 & $+2,18$ & $1 / 0,89$ & 16,95 \\
& 1,5 & 8,61 & $\mathbf{- 3 , 6 9}$ & 9,10 & $+\mathbf{1 6 , 6 7}$ & $1 / 1,06$ & $\mathbf{1 7 , 7 1}$ \\
& 5,0 & 9,35 & $+4,59$ & 7,98 & $+2,31$ & $1 / 0,85$ & 17,33 \\
\hline Эко-Стим Д & 0,5 & 8,93 & $-0,11$ & 8,02 & $+2,82$ & $1 / 0,90$ & 16,95 \\
& 1,5 & 8,19 & $\mathbf{- 8 , 3 9}$ & 9,11 & $+\mathbf{1 6 , 9 1}$ & $1 / 1,11$ & $\mathbf{1 7 , 3 0}$ \\
& 5,0 & 9,13 & $+2,12$ & 7,99 & $+2,44$ & $1 / 0,87$ & 17,95 \\
\hline
\end{tabular}

\section{Заключение}

Таким образом, инновационные биопрепараты Эко-Стим, получаемые путем карбоксиметилирования различных видов растительного сырья (в том числе растительных отходов), можно применять в качестве регуляторов роста различных сельскохозяйственных культур. Исследованные препараты показывают высокую ростостимулирующую активность как при внесении их в сухом виде, так и при обработке растворами.

\section{Список литературь}

1. Цыганкова В.А., Галкина Л.А., Мусатенко Л.И., Сытник К.М. Генетический и эпигенетический контроль роста и развития растений. Гены биосинтеза ауксинов и ауксин-регулируемые гены, контролирующие деление и растяжение клеток растений // Біополімери и клітина. 2005. Т. 21, №2. С. 107-133.

2. Елькина Е.А., Шубаков А.А., Оводов Ю.С. Влияние растительных полисахаридов на скорость прорастания семян Lycopersicon Esculentum M. и Cucumis Sativus L. // Химия растительного сырья. 2002. №2. С. 105-109.

3. Шахматов Е.Г., Михайлова Е.А., Макарова Е.Н. Структурно-химическая характеристика и биологическая активность полисахаридов Heracleum Sosnowskyi Manden // Химия растительного сырья. 2015. №4. С. 15-22.

4. Arteca R.N. Plant Growth Substances. Boston, 1996. 347 p.

5. Basra A.S. Plant growth regulators in agriculture and horticulture. New York, 2000. 264 p.

6. Патент №2130947 (РФ). Способ карбоксиметилирования лигноуглеводных материалов / Галочкин А.И., Маркин В.И., Базарнова Н.Г., Заставенко Н.В., Крестьянникова Н.С. / 1999.

7. Патент №2135517 (РФ). Способ карбоксиметилирования лигноуглеводных материалов / Базарнова Н.Г., Токарева И.В., Галочкин А.И., Маркин В.И. / 1999.

8. Патент №2131884 (RU). Способ карбоксиметилирования лигноуглеводных материалов / Базарнова Н.Г., Маркин В.И., Галочкин А.И., Токарева И.В. / 1999.

9. Маркин В.И. Карбоксиметилирование растительного сырья. Теория и практика. Барнаул, 2010. 167 с.

10. Ishikawa H., Evans M. Comparative growth and gravitropsim studies in auxin response mutants of Arabidopsis thaliana // Biological sciences in space. 1993. N2. Pp. 133-144.

11. Маркин В.И., Феллер С.В. Расчет методом молекулярной механики некоторых карбоксиметилированных фрагментов лигнина // Новые достижения в химии и химической технологии растительного сырья : материалы V Bсерос. конф. с междунар. участием. Барнаул, 2012. С. 95-97.

12. Маркин В.И., Феллер С.В. Карбоксиметилированные фрагменты лигнина, как регуляторы роста растений // Фенольные соединения: фундаментальные и прикладные аспекты : материалы IX Междунар. симпозиума. М., 2015. C. $367-371$. 
13. Феллер С.В., Маркин В.И., Базарнова Н.Г. Росторегулирующие свойства карбоксиметилированной древесины сосны // Аграрная наука - сельскому хозяйству : сборник статей V Междунар. науч.-практ. конф. : в 3 кн. Барнаул, 2010. Кн. 2. С. 125-127.

14. Мальцев М.И., Александрова Т.Н., Калюта Е.В. Из опыта по применению карбоксиметилированных композиций в качестве регуляторов роста пшеницы, полученных из продуктов переработки растительного сырья // Аграрная наука - сельскому хозяйству : сборник статей X Междунар. науч.-практ. конференции : в 3 кн. Барнаул, 2015. Кн. 2. С. $152-154$.

15. Базарнова Н.Г., Катраков И.Б., Маркин В.И., Верещагина Т.В., Жилина И.Н., Уткова Е.А., Борисова Г.И., Семенков А.А. Росторегулирующие полимерные композиции на основе химически модифицированного растительного сырья для выращивания овощных культур, производимых тепличными технологиями // Вестник алтайской науки. 2013. №1. С. 39-42.

16. Базарнова Н.Г., Тихомирова Л.И., Фролова Н.С., Павлушин А.Е., Курчанова Е.А. Влияние стимулятора роста растительного происхождения на морфогенез Iris Sibirica L., Hedysarum Teinum Krasnob. Syringa Vulgaris L. в культуре in vitro // Химия растительного сырья. 2013. №3. С. 243-248.

17. Ступина Л.А., Калюта Е.В., Маркин В.И. Влияние карбоксиметилированной половы овса и ризоторфина на продуктивность сои в условиях колочной степи Алтайского края // Новые достижения в химии и химической технологии растительного сырья : материалы VI Всероссийской конференции. Барнаул, 2014. С. 103-105.

18. Калюта Е.В., Мальцев М.И., Маркин В.И., Катраков И.Б., Базарнова Н.Г. Исследование влияния карбоксиметилированного растительного сырья на активность прорастания яровой мягкой пшеницы // Химия растительного сырья. 2013. №3. С. 249-253.

19. Оболенская А.В., Ельницкая Э.П., Леонович А.А. Лабораторные работы по химии древесины и целлюлозы. М., 1991. $320 \mathrm{c}$.

20. Чепрасова М.Ю., Маркин В.И. Карбоксиметилирование растительного сырья под воздействием микроволнового излучения. Барнаул, 2014. 96 с.

21. Калюта Е.В., Базарнова Н.Г., Маркин В.И. Влияние продолжительности обработки надуксусной кислотой карбоксиметилированной древесины на свойства выделяемой карбоксиметилцеллюлозы // Химия растительного сырья. 2006. №2. С. 29-31.

22. Доспехов Б.А. Методика полевого опыта (с основами статистической обработки результатов исследований). М., 2011. $352 \mathrm{c}$.

Поступило в редакиию 28 ноября 2015 г.

После переработки 14 апреля 2016 г. 
Kaljuta E.V., Mal'cev M.I., Markin V.I., Katrakov I.B., Bazarnova N.G. APPLICATION OF INNOVATIVE PRODUCTS ECO-STIM AS CROP GROWTH REGULATORS

${ }^{I}$ Altai State Agrarian University, Krasnoarmejskij ave., 98, Barnaul, 656049 (Russia) e-mail: kalyuta75@mail.ru

${ }^{2}$ Altai State University, Lenina ave., 61,Barnaul,656049(Russia),e-mail:markin@chem.asu.ru

Agricultural enterprises have a need to use available, cheap stimulants plant growth, which should be not only effective but environmentally safe for the environment. In the present study we investigated innovative growth regulator Eco-Stim, resulting carboxymethylation different types of plants (pine wood, oat chaff, sunflower husks). To obtain it, you can use crop residues, which will also help to solve the problem of waste disposal plant in enterprises engaged in agricultural production. The effect of the method of application (making in powder form to the soil, seed treatment with an aqueous solution irrigating plants at different stages of the growing season), and the carrier portion. The effect of "Omsk-36" Eco-Stim drugs on growth and development of wheat varieties, "Zasolochniy" varieties of cucumbers, radish "Presto" variety as in industrial production and the cultivation of plants in small spaces. It was established that all studied drugs have growth regulating activity and may be used in various crops as growth regulators in making it in a dry form, and for seed treatment solutions or watering plants at different growing stages. The greatest growth promoting effect was observed when using aqueous solutions.

Keywords: plant material, carboxymethylation, growth stimulator, auxins, Eco-Stim.

\section{References}

1. Cygankova V.A., Galkina L.A., Musatenko L.I., Sytnik K.M. Biopolimery y klityna, 2005, vol. 21, no. 2, pp. 107-133. (in Russ.).

2. El'kina E.A., Shubakov A.A., Ovodov Iu.S. Khimiia rastitel'nogo syr'ia, 2002, no. 2, pp. 105-109. (in Russ.).

3. Shakhmatov E.G., Mikhailova E.A., Makarova E.N. Khimiia rastitel'nogo syr'ia, 2015, no. 4, pp. 15-22. (in Russ.).

4. Arteca R.N. Plant Growth Substances. Boston, 1996. 347 p.

5. Basra A.S. Plant growth regulators in agriculture and horticulture. New York, 2000. $264 \mathrm{p}$.

6. Patent 2130947 (RU). 1999. (in Russ.).

7. Patent 2135517 (RU). 1999. (in Russ.).

8. Patent 2131884 (RU). 1999. (in Russ.).

9. Markin V.I. Karboksimetilirovanie rastitel'nogo syr'ia. Teoriia i praktika. [Carboxymethylation of vegetable raw materials. Theory and practice]. Barnaul, 2010, 167 p. (in Russ.).

10. Ishikawa H., Evans M. Biological sciences in space, 1993, no. 2, pp. 133-144.

11. Markin V.I., Feller S.V. Novye dostizheniia v khimii i khimicheskoi tekhnologii rastitel'nogo syr'ia : materialy $V$ Vseros. konf. s mezhdunar. uchastiem. [New advances in chemistry and chemical technology of vegetable raw materials: materials V All-Russian conference with international participation]. Barnaul, 2012, pp. 95-97. (in Russ.).

12. Markin V.I., Feller S.V. Fenol'nye soedineniia: fundamental'nye i prikladnye aspekty : materialy IX Mezhdunar. simpoziuma. [Phenolic compounds: fundamental and applied aspects: Materials of the IX International Symposium]. Moscow, 2015, pp. 367-371. (in Russ.).

13. Feller S.V., Markin V.I., Bazarnova N.G. Agrarnaia nauka - sel'skomu khoziaistvu : sbornik statei V Mezhdunar. Nauch.-prakt. konf. [Agricultural science - agriculture: a collection of articles V international scientific-practical conference]. Barnaul, 2010, vol. 2, pp. 125-127. (in Russ.).

14. Mal'tsev M.I., Aleksandrova T.N., Kaliuta E.V. Agrarnaia nauka-sel'skomu khoziaistvu: sbornik statei X Mezhdunar. Nauch.-prakt. konf. [Agricultural science - agriculture: a collection of articles $\mathrm{X}$ international scientific-practical conference]. Barnaul, 2015, vol. 2, pp. 152-154. (in Russ.).

15. Bazarnova N.G., Katrakov I.B., Markin V.I., Vereshchagina T.V., Zhilina I.N., Utkova E.A., Borisova G.I., Semenkov A.A. Vestnik altaiskoi nauki, 2013, no. 1, pp. 39-42. (in Russ.).

16. Bazarnova N.G., Tikhomirova L.I., Frolova N.S., Pavlushin A.E., Kurchanova E.A. Khimiia rastitel'nogo syr'ia, 2013, no. 3, pp. 243-248. (in Russ.).

17. Stupina L.A., Kaliuta E.V., Markin V.I. Novye dostizheniia v khimii i khimicheskoi tekhnologii rastitel'nogo syr'ia : materialy VI Vserossiiskoi konferentsii. [New advances in chemistry and chemical technology of vegetable raw materials: the VI All-Russian Conference]. Barnaul, 2014, pp. 103-105. (in Russ.).

18. Kaliuta E.V., Mal'tsev M.I., Markin V.I., Katrakov I.B., Bazarnova N.G. Khimiia rastitel'nogo syr'ia, 2013, no. 3, pp. 249-253. (in Russ.).

19. Obolenskaia A.V., El'nitskaia E.P., Leonovich A.A. Laboratornye raboty po khimii drevesiny $i$ tselliulozy. [Laboratory work on the chemistry of wood and cellulose]. Moscow, 1991, 320 p. (in Russ.).

20. Cheprasova M.Iu., Markin V.I. Karboksimetilirovanie rastitel'nogo syr'ia pod vozdeistviem mikrovolnovogo izlucheniia. [Carboxymethylation vegetable raw materials under microwave irradiation]. Barnaul, 2014, 96 p. (in Russ.).

21. Kaliuta E.V., Bazarnova N.G., Markin V.I. Khimiia rastitel'nogo syr'ia, 2006, no. 2, pp. 29-31. (in Russ.).

22. Dospekhov B.A. Metodika polevogo opyta (s osnovami statisticheskoi obrabotki rezul'tatov issledovanii). [Methods of field experience (with the fundamentals of statistical processing of the results of research).]. Moscow, 2011, 352 p. (in Russ.).

Received November 28, 2015 